\title{
Monitoring the Spread of Xanthomonas Campestris pv. Dieffenbachiae Introduced from Symptomless Anthurium Cuttings into Production Fields
}

\author{
David J. Norman ${ }^{1}$ and Anne M. Alvarez \\ Department of Plant Pathology, University of Hawaii, Honolulu, HI 96822
}

\begin{abstract}
In field crops the origin and movement of bacterial inoculum is difficult to determine due to inadequate means of distinguishing strains of bacteria. In this study the introduction, establishment, and spread of Xanthomonas campestris pv. dieffenbachiae (McCulloch and Pirone) Dye into anthurium fields were examined by monitoring the distribution of serologically distinct strains recovered from propagation benches and production fields. One thousand Anthurium andraeanum Lind. plants were indexed for $X . c$. pv. dieffenbachiae and 962 were later introduced into a production field. Strains recovered from the propagative stock were serotyped using a panel of 10 monoclonal antibodies and serotypes were compared to serotypes of strains already prevalent in the production field. Four distinct serotypes were identified which were not characteristic of strains already prevalent in the production field. Two biotypes of $X$. $c$. pv. dieffenbachia were also identified, based on their ability to hydrolyze starch. Sensitivity to $500 \mathrm{ppm}$ streptomycin sulfate also was used to characterize strains associated with introduced propagative stock. Of 248 strains isolated from field plants, $39 \%$ were streptomycin resistant, whereas none of the strains isolated from introduced cuttings at the initial indexing were resistant. Over a 3-year period, strains with serotypes associated with the propagation material became established in the field, but spread to other cultivars was limited. This paper demonstrates the utility of serological methods for epidemiological studies.
\end{abstract}

The period of time from initial infection of a plant by a pathogen to onset of symptoms is considered to be the latency period. Length of time various pathogens exist in this stage without symptom expression is not well established. The existence of phytobacteria within host tissue may not induce any gross change in form or function of the host (Hayward, 1974). Assessment of latent infections in propagating material is important for crop production and enhances the accuracy of epidemiological studies. Latent infections have been demonstrated in a number of pathosystems, such as, Corynebacterium sepedonicum (Spieck. and Kotth.) Davis in potato (Gudmestad et al., 1991), Xanthomonas campestris pv. pelargonii (Brown) Dye in geranium (Anderson et al., 1990), and Agrobacterium tumefaciens (Smith and Townsend) Conn in grape (Bishop et al., 1989).

Sanitation and production of disease-free propagation stock have been recommended in an integrated program to control anthurium blight caused by Xanthomonas campestris pv. dieffenbachiae (Cook, 1988; Nishijima and Fujiyama, 1985; Tanabe et al., 1990). Nevertheless, when symptomless anthurium plants have been used as propagative stock, outbreaks of anthurium blight occur in production fields. In such cases it is difficult to determine whether the pathogen was introduced on latently infected cuttings or if it was spread from contaminated plants already present in the production area. Determining the origins of inoculum and monitoring the distribution of $X . c$. pv. dieffenbachiae in anthurium fields are difficult because the introduced inoculum must be distinguished from the pathogen populations already present in the field. Using monoclonal antibodies (MAbs) sub-

Received for publication 12 June 1995. Accepted for publication 21 Dec. 1995 Florida Agricultural Experiment Station journal series no R-04992. We gratefully acknowledge Albert Benedict, Head of the Monoclonal Antibody Facility, and Carla Mizumoto, Dept. of Microbiology, Univ. of Hawaii for assisting in the generation of the monoclonal antibodies used in this study. The cost of publishing this paper was defrayed in part by the payment of page charges. Under postal regulations, this paper therefore must be hereby marked advertisement solely to indicate this fact.

${ }^{1}$ Current address: Univ. of Florida, Plant Pathology Dept., Central Florida Research and Education Center, 2807 Binion Rd., Apopka, FL 32703. populations of $X . c$. pv. dieffenbachiae can be differentiated (Lipp et al., 1992) and the establishment of new strains in production areas can be monitored. In this study MABs were utilized to differentiate populations of $X . c$. pv. dieffenbachiae to determine the following: a) if pathogens were being introduced to anthurium production fields via latently infected propagation material, and b) if $X . c$. pv. dieffenbachiae is being introduced via latently infected plants is it becoming established in the production area.

\section{Materials and Methods}

In the present study, the pathogen was recovered from symptomless plants using semi-selective isolation media (Norman and Alvarez, 1989), and distribution of distinct bacterial populations on the propagation bench and in the production field was determined by serotyping with a panel of ten MAbs. 1000 symptomless anthurium plants were introduced to an isolated propagation area from a distant farm, indexed for $X . c$. pv. dieffenbachiae, propagated through cuttings, grown in an isolated propagation house and later transplanted to the production field where the spread of the pathogen was monitored for three years.

Monoclonal antibodies. The 10 MAbs used in this study consisted of two genus-specific MAbs, X1, and X11 (Alvarez et al., 1985), six previously described MAbs (Lipp et al., 1992), MAb Xcd 108 (Norman and Alvarez, 1994), and a recently developed MAb designated Xcd 30, which was produced following immunization of a mouse (strain BALB/c) with X. c. pv. dieffenbachiae strain D150 from anthurium, using previously described methods (Alvarez et al., 1985). Reactivity of the new MAb was tested with X. albilineans (Ashby) Downson (1 strain), X. citri (Hasse) Dye (6 strains), X. maltophilia (Hugh) (5 strains), X. oryzae (Ishiyama) Dye (5 strains), and 87 strains from 21 other pathovars of $X$. campestris.

Characterization of X. c. pv. dieffenbachiae in the production field. 282 plants from the flower production area of a 8.1 hectare anthurium farm were assayed for $X . c$. pv. dieffenbachiae. Shade cloth houses were divided into sections of about $58.8 \mathrm{~m}^{2}$. Within each of these sampling areas at least two leaf samples showing 
blight symptoms were collected. Samples were numbered as to sample location and cultivar and placed into individual plastic bags to avoid cross contamination. In the laboratory, a $6 \mathrm{~mm}$-diameter leaf disk was removed from each leaf sample using a sterile cork borer. Individual leaf disks were placed into test tubes containing $1 \mathrm{ml}$ of sterile $0.85 \%$ saline. Samples were soaked for $1 \mathrm{~h}$, after which $20-\mu 1$ subsamples were spotted onto cellobiose-starch (CS) and esculin-trehalose (ET) media (Norman and Alvarez, 1989). Colonies that developed in 4 days were dilution streaked onto modified triphenyltetrazolium chloride medium (TZC) (Norman and Alvarez, 1989) to check for purity. Individual colonies were then transferred to a yeast dextrose (YD) medium (glucose, 20 $\mathrm{g} \cdot \mathrm{liter}^{-1}$; yeast extract, $10 \mathrm{~g} \cdot \mathrm{liter}^{-1}$; agar, $\left.17 \mathrm{~g} \cdot \mathrm{liter}^{-1}\right)$. Bacteria were subsequently harvested from YD medium and stored at $4 \mathrm{C}$ in vials containing $1.5 \mathrm{ml}$ of sterile phosphate buffered saline. Bacterial samples were later revived and grown at 29C for $48 \mathrm{~h}$ on yeast glycerol agar (YGA) medium (Benedict and Alvarez, 1990) from which they were harvested and coated onto ELISA plates following procedures of Yuen et al. (1987). The serotypes of each strain were determined by ELISA using the panel of ten aforementioned MAbs. Bacteria also were tested for streptomycin resistance and the ability to hydrolyze starch. Cell suspensions from $48 \mathrm{~h}$ cultures were adjusted to about $10^{8} \mathrm{cfu} / \mathrm{ml}$ (Kolmer, 1959), and $20 \mu \mathrm{l}$ aliquots were spotted onto cellobiose-starch medium with or without streptomycin sulfate $(500 \mathrm{ppm})$. Growth and zones of hydrolysis were recorded after incubation for 4 days at 29C.

Characterization of $X . c$. $p v$. dieffenbachiae recovered from propagation stock. In order to assess the impact of inoculum harbored in latently infected plants and to monitor possible spread of an introduced pathogen, 3000 'Rainbow' anthurium plants destined for propagation at the farm were obtained in $7.6-\mathrm{cm}$ pots $\left(318 \mathrm{~cm}^{2}\right)$. The nursery where these plants were obtained was located $5 \mathrm{~km}$ away from the production field. The plants consisted of at least two leaves and some aerial roots; they were about $25 \mathrm{~cm}$ from base to tip. Before propagation and indexing, plants showing blight symptoms were removed. From these, bacteria were isolated and tested with MAbs as described to determine which serotypes were present.

Shoots of 1000 symptomless plants were cut for propagation using shears dipped in a 1:1 ratio of $35 \%$ isopropyl alcohol / lethal dose (LD) disinfectant (Tanabe et al., 1990). Basal sections retained at least two leaves and cut surfaces were sealed by applying a pruning seal with a stick applicator. A stem section about $10 \mathrm{~mm}$ long was removed from the base of each shoot, placed individually in labeled polyethylene bags, and transported to the laboratory for indexing. Tissue samples were immersed in $10 \%$ clorox $(0.5 \%$ $\mathrm{NaOCl}$ ) for about $15 \mathrm{sec}$, rinsed in sterile distilled water, bissected, and placed in $1 \mathrm{ml}$ of sterile saline. After $1 \mathrm{~h}, 20-\mu \mathrm{l}$ subsamples of exudate were spotted onto CS and ET media. Strains isolated were serotyped as previously described.

Each shoot was planted in a $7.6-\mathrm{cm}\left(318-\mathrm{cm}^{2}\right)$ pot and tagged with the number of the plant from which it was derived. When $X$. c. pv. dieffenbachiae was recovered from a stem section, the corresponding propagules (stem cuttings and basal sections) were discarded. All xanthomonads recovered in this manner were as follows: a) tested for the ability to hydrolyze starch; b) tested for resistance to streptomycin; and c) serotyped with MAbs. The block of plants containing 1000 shoot tips was separated from the block of 1000 basal sections by a 7-ft plastic barrier. A 50-ft buffer zone containing no plants surrounded the propagation benches which were further separated from the production fields by shade cloth partitions from floor to ceiling. Plants were watered by an overhead misting system and workers were not allowed to enter the block if they had previously been in any flower production area.

Four plants that tested positive with MAbs were removed following the first indexing. After 5 months, a second propagation and indexing was made on 852 of the original 1000 plants indexed, which had developed three leaves. The remaining 144 plants were not indexed because they were too small for propagation. Indexing was performed as previously described.

Monitoring distribution of $X . c . p v$. dieffenbachiae in propagated cuttings and field plants. Of the 1000 plants originally indexed, 967 of the top cuttings were subsequently planted in the production field in close proximity to existing production beds. Production beds were separated by a $1.83 \mathrm{~m}$ high shade cloth fences. During the first year, plants with blight symptoms were removed and assayed for $X . c$. pv. dieffenbachiae. Distribution of infected plants on the propagation bench and in the field was examined using the 2DCLASS two-dimensional distance analysis (Nelson et al., 1992). Propagated plants in the field were sampled again after 3 years using the miniplate enrichment/ELISA system (Norman and Alvarez, 1994). Strains were recovered, streaked onto TZC medium, and serotyped. During this 3 year period, flowers were harvested and routine sanitation of plants was performed. Leaves exhibiting blight symptoms were collected from the test block and 13 blocks bordering the test block. Samples were handled as described for the previous experiment.

\section{Results}

Monoclonal antibodies. MAb Xcd 30 (clone no. 167-30-83-1 reacted with 9/23 (39\%) X. c. pv. dieffenbachiae strains from anthurium in initial screening and did not react with the strains tested of $X$. albilineans, $X$. citri, $X$. maltophilia, X. oryzae, or 87 strains from 21 other pathovars of $X$. campestris.

Characterization of $X . c . p v$. dieffenbachiae in the production

Table 1. Serotypes of 283 Xanthomonas $c$. pv. dieffenbachiae strains recovered from anthurium production fields and introduced propagative stock in initial indexing.

\begin{tabular}{|c|c|c|c|c|c|c|c|c|c|c|c|c|c|}
\hline \multirow[b]{3}{*}{ Biotype } & \multirow{2}{*}{\multicolumn{11}{|c|}{ Reactivity with monoclonal antibodies }} & \multicolumn{2}{|c|}{ Strains recovered (no.) } \\
\hline & & & & & & & & & & & & \multirow{2}{*}{$\begin{array}{l}\text { Field } \\
\text { plants }\end{array}$} & \multirow{2}{*}{$\begin{array}{l}\text { Propagation } \\
\text { block }\end{array}$} \\
\hline & Sero-type & Xcd108 & $\mathrm{Xc3}$ & Xc16 & $\mathrm{Xc} 2$ & Xcd7 & Xcd30 & Xcd1 & Xc59 & $\mathrm{X} 1$ & $\mathrm{X} 11$ & & \\
\hline$\overline{\mathrm{A}}$ & 1 & + & + & + & + & + & + & + & - & + & + & & 3 \\
\hline A & 2 & + & + & + & + & - & + & + & - & + & + & & 1 \\
\hline A & 3 & + & + & + & + & + & + & - & - & + & + & & 15 \\
\hline A & 4 & + & + & + & + & - & - & - & - & + & + & & 2 \\
\hline B & 5 & + & + & + & - & + & + & - & - & + & + & 246 & 11 \\
\hline B & 8 & + & + & + & - & - & - & - & + & + & + & & 2 \\
\hline B & 12 & - & - & - & - & - & - & - & - & + & + & 2 & 1 \\
\hline Total & & & & & & & & & & & & 248 & 35 \\
\hline
\end{tabular}




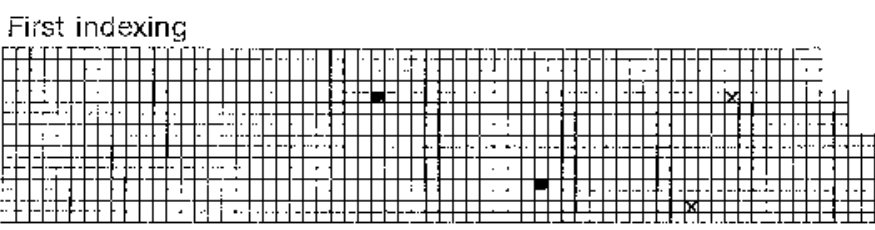

Second indexing

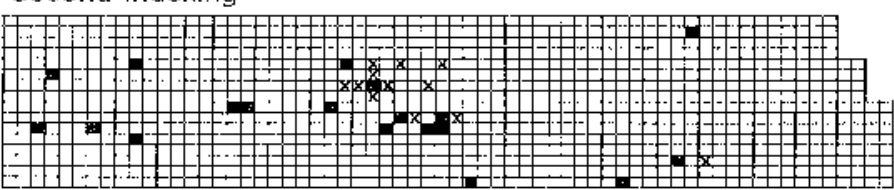

Fig. 1. Spatial patterns of infected plants on the anthurium propagation bench after the first and second indexings. Xanthomonas c. pv. dieffenbachiae biotype A( $\mathbf{\square}$, serotypes 1 to 4 , and biotype B (X), serotypes 5 to 12 .
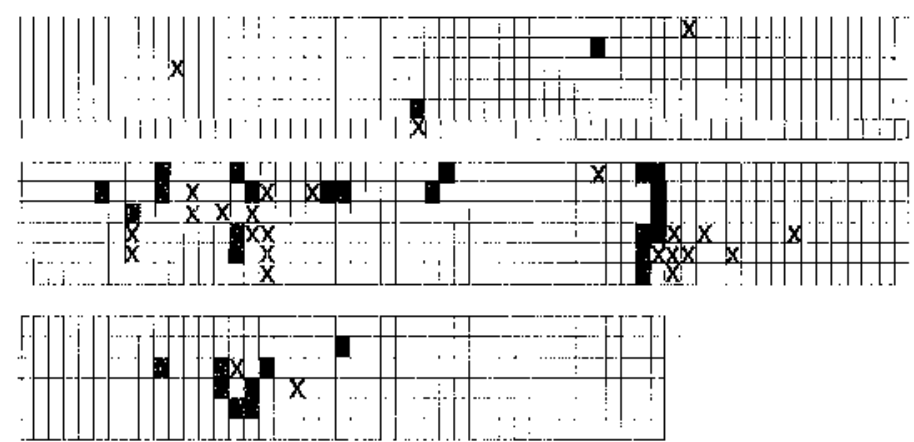

Fig. 2. Spatial pattern of infected anthurium plants within three rows of growth beds within first year after transplanting into the field. Xanthomonas c. pv. dieffenbachiae biotype A ( $\mathbf{\square})$, serotypes 1 to 4 , and biotype B (X), serotypes 5 to 12 .

field. $248 X$. . . pv. dieffenbachiae strains were isolated from samples taken from 282 plants in the flower production area. All strains utilized starch and $39 \%$ were resistant to streptomycin sulfate. Two strains were serotype 12 and the remainder were serotype 5.

Characterization of $X . c . p v$. dieffenbachiae recovered from propagation stock. Of about 3000 anthurium plants acquired for propagation, three had blight symptoms from which $X . c . p v$. dieffenbachiae was isolated. The pathogen was recovered from both leaves and stems of these three plants, indicating that systemic infections had occurred. Strains isolated from two plants were of serotype 2 and the third plant contained strains of $X . c . p v$. dieffenbachiae of serotype 5 (data not shown). In the first indexing of 1000 plants, only four $(0.4 \%)$ were systemically infected. Strains were serotypes $2,4,8$, and 12 . Of the 852 plants assayed during the second indexing, $33(3.9 \%)$ were infected, and 21 of the 33 strains (64\%) were in serotypes 1, 2,3, and 4 (Table 1). Strains in serotypes 1 to 4 failed to hydrolyze starch on CS medium and were classified as biotype A, whereas strains in serotypes 5 to 12 hydrolyzed starch and were designated as biotype B (Table 1). Distribution of plants found to be infected with $X$. c. pv. dieffenbachiae in both indexings is shown in Fig. 1.

Monitoring distribution of $X . c . p v$. dieffenbachiae in propagated cuttings and field plants. Of the 967 top cuttings transplanted into the production field, 66 plants $(6.9 \%)$ developed blight symptoms within the first year (Fig. 2). X. c. pv. dieffenbachiae was recovered from $56(85 \%)$ of these plants. Thirty strains of serotypes 1 and 2 were identified, indicating that their source was the initial propagules and not from existing production plants. The two-dimensional distance class analysis of infected plants on the propagation bench and after planting in the field showed a nonrandom distribution of diseased plants $(P \leq 0.05)$. No significant edge effect was detected in the distribution of infected plants in either location, indicating that bacteria were not spreading from existing propagation areas to introduced plants. In the third year, seven strains with serotypes 2 or 4 were isolated from plants in the test block of the production field and all of these were sensitive to streptomycin. During the 3 years of production, about $20 \%$ of the plants in the test block exhibited bacterial blight symptoms and were rogued by the grower.

In a survey of surrounding production fields 3 years after the experiment was initiated, all but one of the strains were a serotype 5 as seen previously. The percentage of streptomycin resistant strains remained between $29 \%$ and $39 \%$ in the production fields surrounding introduced plants (Table 2).

\section{Discussion}

Latent infections in anthurium were demonstrated using 10 MAbs to differentiate bacterial populations recovered from introduced plants from those already present in the production area. These studies demonstrated that even low numbers of latently infected plants may pose a significant risk to subsequent anthurium production. The relatively low blight infestation introduced through the latently infected plants resulted in extensive disease after 3 years, indicating the importance of establishing clean planting

Table 2. Serotypes and antibiotic resistance of Xanthomonas $c$. pv. dieffenbachiae strains recovered from anthurium propagative stock and production field.

\begin{tabular}{l}
\hline \\
\hline
\end{tabular}


stock. This also indicates why sanitation alone has failed to control disease. Little research has been done into studying the resistance of various cultivars of anthurium to $X$. c. pv. dieffenbachiae. It is to be expected that various cultivars would exhibit varying degrees of resistance and that this resistance would influence both the period of disease latency and pathogen spread.

Examination of the establishment, dispersal, and temporal relationships of phytobacteria within a field are rarely undertaken probably because of the technical difficulties involved. The spread of Xanthomonas campestris pv. vesicatoria in tomato fields was examined and mapped by recording disease incidence within fields (Pohronezny et al., 1990). In studies of black rot of cabbage, Yuen et al. (1987) mapped the spread of several X. campestris pv. campestris strains having distinct serotypes as delineated by reactions with four MAbs.

Not all the strains recovered from propagation stock were distinguished from prevalent field strains, but it was clear that strains of serotypes $1,2,3$, and 4 were introduced via latently infected plants and subsequently were moved on these symptomless plants to the field. Strains in serotypes 1 to 4 were found only in the introduced propagative materials whereas strains in serotypes 5 were prevalent in plants from the surrounding production area.

Strains from propagative stock with serotypes 5 and 12 were serologically identical to strains recovered from field plants, but the population differed in that few strains from the propagative stock were resistant to streptomycin. Only after propagative stock was established in the field was a higher percentage of streptomycin resistance observed and then only in three strains of serotypes 5 and 12 . In contrast, $29 \%$ to $39 \%$ of the field strains were resistant. The three strains found in the propagated stock probably were introduced from surrounding production beds. Streptomycin sulfate had been applied in this nursery 5 years earlier in an unsuccessful attempt to control the blight. This selection pressure could account for the prevalence of streptomycin resistant strains resident in the field population (Knauss, 1972; Singh and Chand, 1994; Sundin and Bender, 1994).

The increase of infected anthurium plants from $0.4 \%$ to $4.1 \%$ observed over 5 months on the propagative bench may be attributed to a) latent infections not detected during the first indexing of the stem section, b) aerial spread of bacteria on the propagation bench facilitated by overhead irrigation, c) close proximity of plants which facilitated spread of bacteria through leaf to leaf contact; d) contamination of the pruning seal with $X . c . p v$. dieffenbachiae that subsequently spread to other plants, or e) handling by workers. Modification of these growing practices could potentially reduce disease spread on the propagation bench.

Presence of pathogenic $X$. c. pv. dieffenbachiae in aerosols has been reported by Venette et al. (1992). Nevertheless, it appears from this study that aerosols are not the major means of pathogen dispersal because strains with identical serotypes were not recovered from plantings separated only by $1.83-\mathrm{m}$ high shade cloth fences. This conclusion is supported by earlier research findings (Alvarez et al., 1989) in which strains of distinct serotypes were recovered from adjacent blocks of plants separated by 2- to 3- $\mathrm{m}$ walkways. Spread was probably facilitated by workers who harvest one particular cultivar (color) at a time.

Propagation from cuttings is less expensive than establishing plants from tissue-cultured plantlets, but high risks are associated with this practice because latent infections may occur in planting stock. The failure of strains of serotypes 1 to 4 to spread extensively in the production field was most likely a direct result of roguing plants that eventually developed symptoms, and this attests to the value of sanitation practices recommended for anthurium blight control (Nishijima and Fujiyama, 1985). Growing practices can and should be further modified, if plants were grown under a covered structure and drip irrigated spread of inoculum in water would be eliminated. Latent infected plants could then be allowed to eventually express symptoms and be removed from production without spread to adjacent plants.

\section{Literature Cited}

Alvarez, A.M., A.A. Benedict, and C.Y. Mizumoto. 1985. Identification of xanthomonads and grouping of strains of Xanthomonas campestris pv. campestris with monoclonal antibodies. Phytopathology 75:722-728.

Alvarez, A., R. Lipp, and B. Bushe. 1989. Distribution of anthurium blight bacteria on four Hawaiian farms, p. 20-23 In: J. A. Fernandez and W. T. Nishijima (eds.). Proc. 2nd Anthurium Blight Conf. HITAHR J. Ser. 03.10.89, Univ. Hawaii.

Anderson, M.J. and S.T. Nameth. 1990. Development of a polyclonal antibody-based serodiagnostic assay for the detection of Xanthomonas campestris pv. pelargonii in geranium plants. Phytopathology 80:357-360.

Benedict, A.A. and A.M. Alvarez. 1990. Radioimmunoassay for plant pathogenic bacteria. p. 211-214 In: R. Hampton, E. Ball, and S. De Boer (eds.). Serological methods for detection and identification of viral and bacterial plant pathogens. APS Press, St. Paul, Minn.

Bishop, A.L., T.J. Burr, V.L. Mittak, and B.H. Katz. 1989. A monoclonal antibody specific to Agrobacterium tumefaciens biovar 3 and its utilization for indexing grapevine propagation material. Phytopathology 79:995-998.

Cook, R.J. 1988. Observations and recommendations for control of bacterial blight of anthurium in Hawaii, III. p. 40-42 In: A. M. Alvarez (ed.). Proc. 1st Anthurium Blight Conf. HITAHR J. Ser. 02.04.88, Univ. Hawaii.

Gudmestad, N.C., D. Baer, and C.J. Kurowski. 1991. Validating immunoassay test performance in the detection of Corynebacterium sepedonicum during the growing season. Phytopathology 81:475-480.

Hayward, A.C. 1974. Latent infections by bacteria. Annu. Rev. Phytopathol. 12:8797.

Knauss, J.F. 1972. Resistance of Xanthomonas dieffenbachiae isolates to streptomycin. Plant Dis. Rpt. 56:394-397.

Kolmer, J.A., E.H. Spaulding, and H.W. Robison. 1959. Approved Laboratory Techniques Appleton-Century-Crofts, New York. p. 582-583.

Lipp, R.L., A.M. Alvarez, A.A. Benedict, and J. Berestecky. 1992. Use of monoclonal antibodies and pathogencity tests to characterize strains of Xanthomonas campestris pv. dieffenbachiae from aroids. Phytopathology 82:677-682.

Nelson, S.C., P.L. Marsh, and C.L. Campbell. 1992. 2DCLASS, a two-dimensional distance class analysis software for the personal computer. Plant Dis. 76:427-432. Nishijima, W. and D. Fujiyama. 1985. Bacterial blight of anthurium. Hawaii Coop. Ext. Serv., HITAHR Commodity Fact Sheet AN-4(A) p. 1-3.

Norman, D. and A. Alvarez. 1989. A rapid method for the presumptive identification of Xanthomonas campestris pv. dieffenbachiae and other xanthomonads. Plant Dis. 73:654-658.

Norman D.J. and A.M. Alvarez. 1994. Rapid detection of Xanthomonas campestris pv. dieffenbachiae in anthurium plants with a miniplate enrichment/ELISA system. Plant Dis. 78:954-958.

Pohronezny, K., M.A. Moss, W. Dankers, and J. Schenck. 1990. Dispersal and management of Xanthomonas campestris pv. vesicatoria during thinning of directseeded tomato. Plant Dis. 74:800-805.

Singh, R. and R. Chand. 1994. Distribution of resistance to copper, zinc and streptomycin in Xanthomonas campestris pv. vesicatoria (Doidge) dye in India and its impact on control of bacterial spot of tomato. J. Plant Dis. Protection 101:80-85.

Sundin, G.W. and C.L. Bender. 1994. Relative fitness in vitro and in planta of Pseudomonas syringae strains containing copper and streptomycin resistance plasmids. Can. J. Microbiol. 40:279-285.

Tanabe, M.J., J. English, P. Moriyasu, C. Arakawa, and T. Matsumoto. 1990. Anthurium in vitro culture, p. 54-55 In A.A. Alvarez (ed.). Proc. 3rd Anthurium Blight Conf. HITAHR J. Ser. 05.07.90, Univ. Hawaii.

Venette, J., A. Alvarez, and D. Norman. 1992. Serological markers for monitoring Xanthomonas campestris pv. dieffenbachiae in aerosols. Phytopathology 82:1178. (Abstr.)

Yuen, G.Y., A.M. Alvarez, A.A. Benedict, and K.J. Trotter. 1987. Use of monoclonal antibodies to monitor the dissemination of Xanthomonas campestris pv.campestris. Phytopathology 77:366-370. 